\title{
The Importance of Integrated Management Systems in Pharmacy
}

DAVOR J. KORČOK, Abela Pharm d.o.o, Quality and Management Department, Belgrade

NADA A. TRŠIĆ-MILANOVIĆ, Abela Pharm d.o.o, Quality and Management Department, Belgrade BOGDAN S. MITIĆ, Abela Pharm d.o.o, Quality and Management Department, Belgrade NIKOLA M. KARADŽIĆ, Univesity of Belgrade, Faculty of Mining And Geology, Belgrade
Professional paper UDC: $658: 615$

DOI: 10.5937/tehnika2001120K

Quality management is very important segment of business in pharmaceutical industry which primary objective is to provide a quality product to customer for the purpose of preserving human health. The increasing number of companies apply numerous quality systems, hence the need for a comparative review of quality management systems and its optimization in order to find suitable model for the integration of these systems. The improvement of integrated management and quality systems has become an imperative of company's business development and survival. It is economically acceptable to use synergy potential in the field of quality management for the purpose of significantly improving company's business competitive position with a relatively small investment. In addition to this, with the integration of different management systems companies become more agile, profitable and more competitive, which is a condition for its survival on the global marketplace. Integrated management systems combine all the components of management systems into a coherent system thus enabling the achievement of company's policy and goals. Basically, there are three approaches for establishment of integrated quality management systems: the Sequential approach, Parallel approach and Combined approach.

Key words: quality management systems, pharmacy, integrated management systems

\section{INTRODUCTION}

Pharmacy is defined by specific regulations, and their compliance and application ensure the quality, safety and efficiency of the finished product. Quality management is very important segment of the business in the pharmaceutical industry where the primary objective is to provide the customer with a quality product in order to preserve human health and the quality of life.

Quality control in the pharmaceutical industry. must be maintained: in the manufacturing process, at the beginning and during the process, on the finished product (product series) and on samples taken from the

Author's address: Davor Korčok, Abela Pharm d.o.o, Quality and Management Department, Belgrade, Viline vode $b b$

e-mail: davorkorcok@abelapharm.rs

Paper received: 29.01.2020.

Paper accepted: 11.02.2020. market (post-market control). It is based on the application of good manufacturing practice ( $\mathrm{Vo}-$ lume 4 Good Manufacturing Practice for Medicinal Products for Human and Veterinary Use) [1]

The application of good manufacturing practice guidelines is a legal obligation, and without the application of these guidelines, it is not possible to obtain a manufacturing authorization and a market approval. In order to improve the quality of business in the early 1990s, an increasing number of pharmaceutical companies are opting to implement a quality management system in accordance with the requirements of ISO standard 9000. During the last few years, with the introduction of legislation for the production and marketing of dietary products, the need to implement a food safety system has been imposed as a requirement by the Codex Alimentarius [2].

With the introduction of ISO 22000 the management of the food safety system was defined, 
which aims to comply with the principles of the Codex Alimentarius and the structure of the ISO 9001:2015 standard (previous version ISO 9001:2008) [3] and standard SRPS ISO 22000:2018, Institute for Standardization of Serbia, 2018.

Since a growing number of companies are implementing these quality and food safety systems, hence the need to compare them and to optimize them in order to find the right model for their integration.

The improvement of integrated management and quality systems has become an imperative for the development and survival of companies. It is economically sustainable to exploit the synergistic potential in the quality management part and to significantly improve the competitive position of the company with relatively small investments. This way, by integrating different management systems, companies become more agile, more profitable and more competitive, which is a prerequisite for survival in the global market.

Integrated management systems represent systems that integrate all components of a management system into one coherent system, enabling the fulfilment of the organization's policies and objectives. Integrated management systems are complex, dynamic systems and their design and implementation are accompanied by risk, cost and other implementation problems.

Nowadays, the application and certification of different management systems is becoming a priority for the long-term sustainable development of each organization.

The concept of integrated management systems must be set up as a set of interconnected processes that use common resources, in order to meet the requirements of all stakeholders.

Growth is a key strategy for organizations in the 21 st century. Stagnation and maintenance of a stationary position for a company is not possible - a nongrowing company is beginning to decline. The application of concepts of quality management is based on the premise that a company cannot survive by maintaining the status quo. As everything around it changes, maintaining the status - quo means weakening the company, so the organization must establish a process of improvement and innovation, in order to have sustainable success and growth. Otherwise, negative trends develop which would lead to its decline.

The sustainable development, success and growth of an organization depends on many macro and micro factors. At the macro level, the prosperity of society as a whole is achieved with the existence of cultural differences and similarities, with great technological leaps and visions of what society and work should be in two or twenty years, but also the threat to the environment, human health and safety. Trace elements within an organization include leadership, changes in management style, employee-customer relationships, self-assessment, benchmarking, knowledge management and motivation to harness the potential of employees.

Growth is a key strategy for organizations in the 21 st century. Stagnation and maintaining a stationary position for a company are not possible - a non-growing company is beginning to decline. The application of the concept of quality management is based on the premise that a company cannot survive by maintaining the status quo. As everything around it changes to maintaining the status quo means weakening the company, so the organization must establish a process of improvement and innovation, in order to have sustainable success and growth. Otherwise, there are negative trends leading to its decline.

Everything is changing dramatically in the world we live in, so not only that these changes are not permanent, but they are rapidly accelerating. The changes are driven by increasing liberalization and huge political and socio-economic upheavals around the world. Technology is changing dramatically fast.

This has a powerful effect on just about everyone, and communication in particular. Development, growth and change can be complementary factors if a dynamic internal change process is established within the company that responds to external changes and ensures its market competitiveness. The key elements of this process that respond to the dizzying changes and ensure the growth of the company are continuous improvements and innovations, which include:

- the learning process (from others and from their own experiences);

- abrupt improvements and breakthroughs;

- incremental improvements;

- innovation

Continuous improvements and innovations are an internal response to changes in the environment, and represent changes in the environment where we work, changes in managing and measuring business process performance, changes in products and in business performance itself.

This means that everything that is done is never good enough and that sometimes the best performance can always be surpassed. The goal of such changes is to sustainably achieve the longterm goals of the organization, and where possible the excellence of the internal organization and outputs. 


\section{INTEGRATED QUALITY MANAGEMENT SYSTEM}

In order to successfully integrate different standardized management systems into a single management system, the following integration elements must be established:

- TQM concept - the basis of integration;

- Integration methodology and process;

- Relationship between requirements of different standards.

The following should be taken into account when expanding the documentation:

- Documents must cover all requirements of all partial standards;

- An Integrated Standard document must not contradict any of the partial standards;

- The documentation generated must be with links and points of contact between the partial management systems;

- The documentation must comply with the legal requirements of all partial standards, systems related to the topic defined by the document.

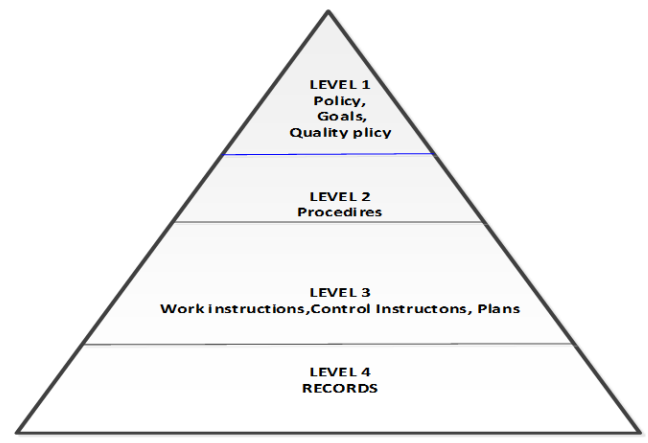

Figure 1 - Documentation hierarchy

\subsection{Implementation of integrated management system at Abela pharm d.o.o.}

Abela Pharm d.o.o. is a pharmaceutical company engaged in the development, registration, production and sale of pharmaceutical products and food supplements as pharmaceutical dosage products, consumer goods and medical devices. The following quality systems/practices have been implemented: ISO 9001: 2008 (now ISO 9001:2015, Good manufacturing practice, ISO 22000: 2005 (now ISO 22000:2018), ISO 14001:2004 (now ISO 14001:2015), ISO 13485:2012 (now ISO 13485:2016) as well as HACCP principles that are integrated because there are common requirements for all systems and methods for compliance goals $[4,5]$. The integration of these systems was accomplished by first preparing the documentation of the basic standard, in this case ISO 9001:2015 (previous version ISO 9001:2008), and then extending the existing documentation to the specific requirements of other standards and the requirements of the HACCP principles. In order to create a comprehensive integrated system, the requirements of all three quality systems are met [6].

There are three basic approaches to implement integrated quality management systems:

- Sequential approach - proceeds by establishing documentation for one of the basic systems, whether it is QMS or GMP. The disadvantage of this approach is that the product realization process takes too long.

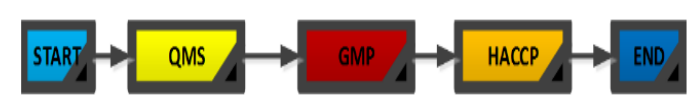

Figure 2 - Sequential approach for integration of $Q M S$

- Parallel approach implies the establishment of all three systems in parallel, whereby common documentation needs to be integrated, and $\mathrm{Qu}$ ality policy needs to explain and relate all other requirements of the standards. The advantages of such an integrated system are that it significantly shortens the time in relation to the sequential approach, but on the other hand, the simultaneous establishment of all three systems can also bring harm, especially if the employees who simultaneously deploy these systems do not have sufficient experience.

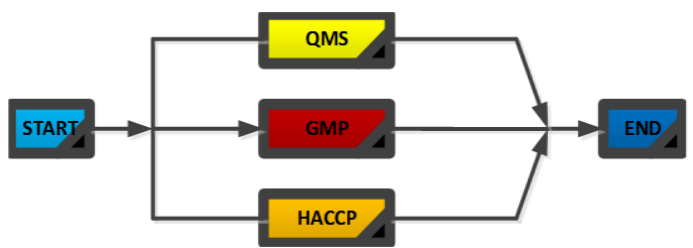

Figure 3 - Parallel approach for integration of $Q M S$

- The combined approach of establishing an integrated system takes advantage of the sequential and parallel approaches. This means that it shrtens the duration of the process while properly loading the participants in the project implementation as well as making better use of other resources. This integration approach was applied by Abela Pharm d.o.o.

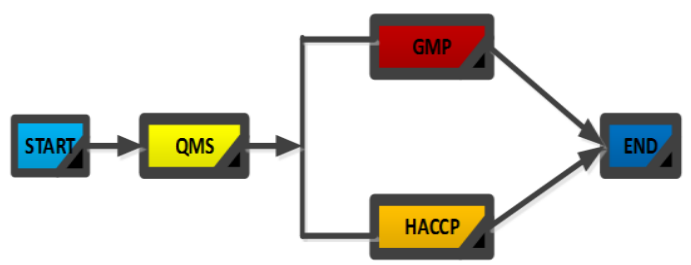

Figure 4 - Combined approach for integration of $Q M S$ 
According to the combined approach of establishing an integrated system, the process of establishing a quality management system according to the requirements of ISO 9001:2015 (previous version ISO 9001:2008) is first implemented. By establishing this management system, employees are introduced to the requirements of the standard, the process of preparation of documentation, the process of implementation and control of documentation. Once a quality management system is in place, the same teams that have worked on recording and improving individual processes continue to work on establishing a Good Manufacturing Practice system and implementing Codex Alimentarius. Based on a comparative review of the requirements of ISO 9001: 2015 (previous version ISO 9001:2008), the requirements of Good Manufacturing Practice and the Codex Alimentarius Management System, it can be concluded that the greatest opportunities for integration of these management systems are in the processes related to: documentation management, records control, education and employee training, non-compliance management, internal audits, corrective and preventative measures, process monitoring and measurement, monitoring of monitoring and measurement equipment, product control and monitoring [7].

One of the goals of integrating quality management systems at Abela Pharm was to reduce the documentation to a level that covers all the requirements of all partial management systems that were selected for the integration without repeating similar requirements more than once and omitting the individual requirement of one of the partial quality systems. Integration of documentation represent the creation of a new expanded documentation at all management levels of an integrated quality system.

\subsection{The effects of integrated $Q M S$}

The advantages of setting up an integrated quality management system at Abela Pharm:

- The commitment and attention of top management is far more certain and focused when the goals, resources and measurements are integrated and when there is a joint review;

- The integration of the management system enables the day-to-day operations to be carried out more effectively without involving the top management, leaving it time for strategic activities;

- Implementation of an integrated management system according to different standards is cheaper and more efficient than the application of individual management systems;

- More efficient integrated multi-focus management system than multiple partial multi-focus management systems;
- It is simpler and more effective to manage integrated goals that have more aspects than managing the goals of individual management systems;

- It is more effective to integrate an integrated management system into an organization's strategy and practice than to integrate individual management systems;

- Implementation and maintenance through integration, testing, verification and validation saves time and money;

- A single process with more aspects is more effective than more separate improvement processes;

- Gaining customer trust and a positive image in the market and in society;

- Integrated systems provide a greater level of control;

- Optimization of priorities when one management representative is focused and in charge of an integrated management system in relation to multiple persons in charge of different systems with their own focuses and priorities;

- A unique training program for an integrated management system saves time and money while reducing the occurrence of employee confusion with messages from separate trainings for different systems;

- A uniform quality, documentation and record policy;

- Cheaper and more efficient internal audit and preparation process for the certification of the integrated management system than the individual ones for each management system;

- Better employee acceptance, less crossfunctional conflicts and greater motivation due to the stated goals of satisfaction of all stakeholders;

- Easier and cheaper certification of integrated management systems.

\section{CONCLUSION}

There is a clear need and legal obligation for organizations involved in the production and marketing of pharmaceuticals to implement the requirements of Good Manufacturing Practices and Codex Alimentarius requirements in their business system, and to obtain a fully-fledged system, the basis of a quality system, a process of the implementation of QMS is proposed. Hence the need to compare the requirements of the management system in order to clearly define common and specific documentation, all in order to create an integrated 
management system that will best meet the requirements of all users, stakeholders and employees.

The integration of individual management systems ensures its greater effectiveness, greater management capabilities for managing the system, greater involvement of top management, saving time and resources.

The biggest integration opportunities are activities related to document management, records control, human resource management, management and control of measurement and monitoring and measurement equipment, process monitoring and control, product monitoring and control, non-compliance, complaints, internal audits, corrective actions and preventive measures.

The integration of the quality management system at Abela Pharm has resulted in a more efficient and effective functioning of the organization at all levels, more effective monitoring of performance, comprehensive monitoring, clear and realistic goal setting that is measurable, as well as their management and, ultimately, the most important in the pharmaceutical industry. A more effective and efficient way of managing, identifying, analysing and assessing risks.

\section{ACKNOWLEDGEMENT}

The authors declare no conflict of interest.

\section{REFERENCES}

[1] Smernice Dobre proizvođačke prakse, Sl. glasnik RS, br. 28/2008 i 35/2008 - ispr, Beograd
[2] Codex Alimentarius. General Principles of food hygiene - Recommended International Code of Practice, CAC/RCP 1-1969, Rev. 4-2003, [Internet], Dostupno na: https://www.mhlw.go.jp/english/topics/importedfoods/guideline/dl/04.pdf

[3] Standard SRPS ISO 9001:2015 - Sistemi menadžmenta kvalitetom - Zahtevi, Institut za standardizaciju Srbije, 2015.

[4] Hartman L. Main elements of a Pharmaceutical Quality System (PQS), Maas \& Peither AG GMP Publishing, Logfile No. 2, 2012.

[5] Bunčić S, (Urednik). Vodič za razvoj i primenu preduslovnih programa i principa HACCP u proizvodnji hrane, Ministarstvo poljoprivrede, šumarstva i vodoprivrede, Uprava za veterinu, Republika Srbija, 155 str, 2009, [Internet], Dostupno na: http://www.vet.minpolj.gov.rs/veterinarsko_javno_zdravstvo/instrukcije_i_vodici/Vo dic\%20za\%20primenu\%20HACCP.pdf

[6] Bauer N, Food Safety Management Systems, Zavod za standardizaciju, Beograd, 2006.

[7] Živković N, Integrisani sistemi menadžmenta, elektronsko izdanje, FON, Beograd, 177 str, 2012, [Internet], Dostupno na: http://kvalitet.fon.bg.ac.rs/wp-content/uploads/IMS-elektronsko-izdanje-dr-Nedeljko-Zivkovic.pdf

\section{REZIME}

\section{ZNAČAJ INTEGRISANIH MENADŽMENT SISTEMA U FARMACIJI}

Upravljanje kvalitetom je vrlo bitan segment poslovanja u farmaceutskoj industriji čiji je osnovni cilj osigurati korisniku kvalitetan proizvod, a sve u cilju očuvanja ljudskog zdravlja. Sve veći broj kompanija primenjuje veliki broj sistema kvaliteta, odakle i potreba za uporednim pregledom sistema upravljanja kvalitetom i njihovom optimizacijom u cilju pronalaženja odgovarajućeg modela za integraciju ovih sistema. Unapređenje integrisanih sistema upravljanja i sistema kvaliteta je postao imperativ razvoja $i$ opstanka preduzeća. Ekonomski je svrsishodno da se iskoristi sinergijski potencijal u oblasti upravljanja kvalitetom i da se uz relativno mala ulaganja značajno unapredi konkurentska pozicija preduzeća. $\mathrm{Na}$ taj način, integracijom različitih menadžment sistema, preduzeća postaju agilnija, profitabilnija i konkurentnija, što je uslov opstanka na globalnom tržištu. Integrisani sistemi upravljanja su sistemi koji integrišu sve komponentne sistema upravljanja u jedan koherentan sistem, omogućavajući postizanje politike i ciljeva preduzeća. U osnovi postoje tri pristupa za uspostavljanje integrisanog sistema upravljanja kvalitetom i to: sekvencijalni pristup, paralelni pristup i kombinovani pristup.

Ključne reči: sistem upravljanja kvalitetom, farmacija, integrisani sistem upravljanja 